\title{
Spectroscopic Characterization, In Vitro Cytotoxicity, and Antioxidant Activity of Mixed Ligand Palladium(II) Chloride Complexes Bearing Nucleobases
}

\author{
Samuel Tetteh, ${ }^{1}$ David K. Dodoo, ${ }^{1}$ Regina Appiah-Opong, ${ }^{2}$ and Isaac Tuffour $^{2}$ \\ ${ }^{1}$ Department of Chemistry, University of Cape Coast, Cape Coast, Ghana \\ ${ }^{2}$ Noguchi Memorial Institute for Medical Research, University of Ghana, Legon, Ghana \\ Correspondence should be addressed to Samuel Tetteh; stoshgh2001@yahoo.com
}

Received 2 December 2013; Revised 15 February 2014; Accepted 28 February 2014; Published 1 April 2014

Academic Editor: Hamdi Temel

Copyright (C) 2014 Samuel Tetteh et al. This is an open access article distributed under the Creative Commons Attribution License, which permits unrestricted use, distribution, and reproduction in any medium, provided the original work is properly cited.

Mixed-ligand palladium(II) chloride complexes bearing the nucleobases, adenine (Ad), cytosine (Cyt), and guanine (Gua), have been synthesized and characterized by UV-vis spectrophotometric methods, magnetic susceptibility, molar conductivity, elemental analysis, FTIR, and ${ }^{1} \mathrm{H}-\mathrm{NMR}$. The complexes were found to have the composition cis- $\left[\mathrm{PdCl}_{2}(\mathrm{Gua})(\mathrm{Cyt})\right], \mathrm{cis}^{-}\left[\mathrm{PdCl}{ }_{2}(\mathrm{Ad})(\mathrm{Cyt})\right]$, and cis- $\left[\mathrm{PdCl}_{2}(\mathrm{Ad})(\mathrm{Gua})\right]$. A four-coordinated square-planar geometry is proposed for these $\mathrm{Pd}(\mathrm{II})$ complexes based on magnetic evidence and electronic spectra. The complexes as well as the free nucleobase ligands were tested for their in vitro cytotoxicity on human promyelocytic leukemia (HL60) and human histiocytic leukemia (U937) cell lines. cis-[PdCl $(\mathrm{Ad})(\mathrm{Gua})]$ showed $\mathrm{IC}_{50}$ values of $11.29 \pm 2.91$ and $8.31 \pm 1.44 \mu \mathrm{M}$ against HL60 and U937, respectively, which was higher than that of the positive control (curcumin) against U937. The complexes also showed significant antioxidant activity when tested against 2,2-diphenyl1-picrylhydrazylradical (DPPH).

\section{Introduction}

The versatility of nucleobases has made them suitable ligands for the synthesis of numerous transition metal complexes [1-5]. In particular, palladium complexes of nucleobases and their derivatives have been of current interest since these complexes form faster than their platinum analogues and produce analogous products in solution $[6,7]$. The mode of bonding and structure of these and related ligands have been exhaustively studied, both spectroscopically and crystallographically [8-11] and have been shown to be monodentate via the $\mathrm{N} 3$ of the pyrimidine and N7 of the purine ligand (as shown in Figure 2). In view of the strong electron withdrawing ability of these metal ions, there is a drift of electron density onto the metal centre and in effect ligand hydrogens are easily lost in the presence of a free radical. This makes these metal complexes act as better antioxidants as compared to the free ligand $[12,13]$.

Mixed-ligand complexes play a key role in biological chemistry [14] because mixed chelation occurs commonly in biological fluids as millions of potential ligands are likely to compete for metal ions in vivo [15]. Because of this profound role, mixed-ligand complexes have been extensively studied for their thermodynamic [16-18] as well as kinetic stability [19-23]. These complexes have received tremendous attention in the search for novel drugs against drug resistant diseases [24-27] with cisplatin being a classic example [28].

Metal based antioxidants have received recent attention for their capacity to protect organisms and cells from damage induced by oxidative stress [12]. An effective antioxidant, however, should be able to terminate the attack of reactive species like free radicals and prevent them from attacking body cells. The antioxidant activity of a synthetic compound can be measured using the scavenging ability of that compound to trap free radicals [13]. Although some palladium(II) complexes of pyrimidine and pyridine derivatives have been synthesized and characterized [1,29], not much has been reported about the antioxidant activity as well as the in vitro cytotoxicity of these complexes. In this study we present the synthesis, spectroscopic characterization, and 
antioxidant as well as in vitro cytotoxicity of palladium(II) complexes with purine and pyrimidine nucleobases as ligands on human promyelocytic leukemia (HL60) and human histiocytic leukemia (U937) cell lines.

\section{Materials and Methods}

2.1. Materials. All the ligands were purchased from Molekula (UK) and the palladium(II) chloride was purchased from Merck KGaA (Germany). These were used without further purification. The DPPH was purchased from Sigma-Aldrich (St. Louis, MO, USA). All other chemicals were of analytical grade and obtained from standard suppliers. Palladium content was analysed spectroscopically using dimethylglyoxime and a modification of the method described by Khader and Prasad [30]. Free radical scavenging ability of the complexes was used as a measure of the antioxidant activity of the complexes. Thiazoyl blue tetrazolium bromide (MTT) assay was used to determine the cytotoxicity of the complexes against U937 and HL60 cell lines.

2.2. Instrumentation and Methods. Chloride content was determined by the Mohr method. ${ }^{1} \mathrm{H}-\mathrm{NMR}$ was recorded in DMSO- $\mathrm{d}_{6}$ on a Gemini 2000 instrument $(400 \mathrm{MHz})$ at room temperature and the ${ }^{1} \mathrm{H}$ chemical shifts referenced to the residual signals of the protons of the NMR solvent quoted in ppm. The IR spectra ( $\mathrm{KBr}$ disks) were recorded on an Interspec 200-X spectrophotometer. Molar conductivity was recorded on a Wagtech 4510 conductivity meter. Electronic absorbance of the complexes was recorded in DMSO on a T70 UV/VIS spectrometer. Melting points of the complexes were determined with a Thermo Scientific Electrothermal Digital Melting Point Apparatus IA9100. Magnetic susceptibility was determined using a modification of the Gouy method [31, 32].

2.3. Synthesis of the Palladium(II) Complexes. The complexes were prepared in a general way as follows: to a $10 \% \mathrm{HCl}$ ethanolic solution $(10 \mathrm{~mL})$ of $\mathrm{PdCl}_{2}(0.354 \mathrm{~g}, 2 \mathrm{mmol})$ was added $2 \mathrm{mmol}$ of one nucleobase ligand in $20 \mathrm{~mL}$ of boiling ethanol. After stirring the mixture at $100^{\circ} \mathrm{C}$ for 30 minutes, $2 \mathrm{mmol}$ of the other ligand dissolved in $20 \mathrm{~mL}$ of boiling ethanol was then added. The resulting solution was refluxed at $100^{\circ} \mathrm{C}$ with stirring for further 45 minutes. The yellow to orange precipitates were suction-filtered and washed with hot ethanol and dried over anhydrous $\mathrm{CaCl}_{2}$.

2.4. Procedure for MTT In Vitro Cytotoxicity. The in vitro cytotoxicity of the compounds was performed on HL60 and U937 cells as described [33]. The cells were maintained in RPMI 1640 medium (containing 10\% FBS and 0.01\% kanamycin). Cells in exponential growth were seeded into 96-well plates at a concentration of $1 \times 10^{4}$ cells $/ 100 \mu \mathrm{L} /$ well. The cells were then treated with various concentrations of the test compounds at a concentration range of $0-200 \mu \mathrm{M}$ for HL60 and $0-100 \mu \mathrm{M}$ for U937 using DMSO as the solvent. Negative control (untreated) and positive control (curcumin) experiments were included.
After 72 hours of incubation at $37^{\circ} \mathrm{C}$ under $5 \%$ $\mathrm{CO}_{2}$ in humidified atmosphere, $20 \mu \mathrm{L}$ of MTT $(3-(4,5-$ dmethylthiazol-2-yl)-2,5-diphenyltetrazolium bromide) was added to each well and the plates were kept in the dark for further 4 hours. Subsequently, $150 \mu \mathrm{L}$ of acidified isopropanol containing Triton-X 100 was added to stop the reaction and also solubilize the formazan crystals formed. Absorbance readings were taken at $570 \mathrm{~nm}$ on a Tecan-PC infinite M200 Pro Plate reader after overnight incubation of the plates. Triplicate experiments were performed. Dose response curves were plotted as percentages of cell viability against concentration. Drug sensitivity was expressed in terms of the concentration of drug required for a $50 \%$ reduction of cell viability $\left(\mathrm{IC}_{50}\right)$. The $\mathrm{IC}_{50}$ values were determined by nonlinear regression analysis.

2.5. Procedure for Antioxidant Activity. The antioxidant activity of the complexes was determined as described $[12,34]$ with slight modifications as follows: on a 96 well plate, the compounds were serially diluted in DMSO to obtain a concentration range of $1.25-20 \mathrm{mM}$. The reaction mixture consisted of $100 \mu \mathrm{L}$ of $0.5 \mathrm{mM}$ 2,2-diphenyl-1-picrylhydrazylradical (DPPH), and $100 \mu \mathrm{L}$ of each concentration of the test compounds using DMSO as the solvent. For positive control, 2,6-di-tert-butyl-4-methylphenol (BHT) was used at a concentration range of $0.0625-2 \mathrm{mM}$ in methanol. The solvents, DMSO and methanol, were used as blanks. Duplicate experiments were performed. The plates were covered with aluminum foil and kept in the dark for 20 minutes after which the absorbance was read on a Tecan-PC infinite M200 Pro Plate reader at the absorbance wavelength of $517 \mathrm{~nm}$. The percent antioxidant activity was calculated as follows:

$$
\left[\text { Percent antioxidant }=\frac{A_{0}-A_{1}}{A_{0}}\right],
$$

where $A_{0}$ is the absorbance of the blank and $A_{1}$ is the absorbance in the presence of the sample or positive control.

\section{Results and Discussion}

3.1. $c i s-\left[\mathrm{PdCl}_{2}(\mathrm{Gua})(\mathrm{Cyt})\right]$. Yield $=0.6905 \mathrm{~g}$ (78.5\%). M.p $(\mathrm{dec})=250^{\circ} \mathrm{C}$. Colour $=$ yellowish brown. Anal. Calcd. for $\mathrm{C}_{9} \mathrm{H}_{10} \mathrm{~N}_{8} \mathrm{O}_{2} \mathrm{PdCl}_{2}$ (\%): $\mathrm{Pd}, 24.21$; $\mathrm{Cl}, 16.16$. found: $\mathrm{Pd}$, 23.91; Cl, 15.81. UV-Vis $\lambda(\mathrm{nm})(\varepsilon): 286\left(19007 \mathrm{M}^{-1} \mathrm{~cm}^{-1}\right)$, 331 (3819 $\left.\mathrm{M}^{-1} \mathrm{~cm}^{-1}\right), 403\left(871 \mathrm{M}^{-1} \mathrm{~cm}^{-1}\right), 531\left(624 \mathrm{M}^{-1} \mathrm{~cm}^{-1}\right)$. $\Lambda_{m}\left(R^{2}\right): 13.58 \Omega^{-1} \mathrm{~cm}^{-2} \mathrm{~mol}^{-1}(0.987) \cdot \mu_{\mathrm{eff}}=0$.

3.2. cis- $\left[\mathrm{PdCl}_{2}(\mathrm{Ad})(\mathrm{Cyt})\right]$. Yield $=0.6905 \mathrm{~g}$ (81.5\%). M.p $(\mathrm{dec})=250^{\circ} \mathrm{C}$. Colour $=$ yellowish brown. Anal. Calcd. for $\mathrm{C}_{9} \mathrm{H}_{10} \mathrm{~N}_{8} \mathrm{OPdCl}_{2}(\%)$ : $\mathrm{Pd}, 26.13 ; \mathrm{Cl}, 16.77$. found: $\mathrm{Pd}$, 26.10; Cl, 16.12. UV-Vis $\lambda(\mathrm{nm})(\varepsilon): 280\left(5149 \mathrm{M}^{-1} \mathrm{~cm}^{-1}\right)$, $331\left(2326 \mathrm{M}^{-1} \mathrm{~cm}^{-1}\right), 406\left(1111 \mathrm{M}^{-1} \mathrm{~cm}^{-1}\right), 531\left(503 \mathrm{M}^{-1} \mathrm{~cm}^{-1}\right)$. $\Lambda_{m}\left(R^{2}\right): 18.48 \Omega^{-1} \mathrm{~cm}^{-2} \mathrm{~mol}^{-1}(0.983) \cdot \mu_{\mathrm{eff}}=0$.

3.3. $c i s-\left[\mathrm{PdCl}_{2}(\mathrm{Gua})(\mathrm{Ad})\right]$. Yield $=0.6812 \mathrm{~g}$ (73.5\%). M.p $(\mathrm{dec})=250^{\circ} \mathrm{C}$. Colour $=$ yellowish brown. Anal. Calcd. for $\mathrm{C}_{10} \mathrm{H}_{10} \mathrm{~N}_{10} \mathrm{OPdCl}_{2}(\%)$ : $\mathrm{Pd}, 22.96$; $\mathrm{Cl}, 15.32$. found: $\mathrm{Pd}$, 
TABLE 1: Major IR $/ \mathrm{cm}^{-1}$ absorption bands of the palladium(II) complexes and the nucleobase ligands.

\begin{tabular}{|c|c|c|c|c|c|c|}
\hline Complex & $v_{\text {as }}\left(\mathrm{NH}_{2}\right)$ & $v_{s}\left(\mathrm{NH}_{2}\right)$ & $v_{s}(\mathrm{C}=\mathrm{O})$ & $v_{s}(\mathrm{C}=\mathrm{N})$ & $\delta_{s}\left(\mathrm{NH}_{2}\right)$ & H-bonding \\
\hline cis- $\left[\mathrm{PdCl}_{2}(\mathrm{cyt})(\mathrm{gua})\right]$ & $3424 \mathrm{w}$ & $3286 \mathrm{~s}$ & $1705 \mathrm{~s}$ & $1634 \mathrm{~s}$ & $1605 \mathrm{~m}$ & $3625-2662 \mathrm{br}$ \\
\hline cis- $\left[\mathrm{PdCl}_{2}(\mathrm{cyt})(\mathrm{ad})\right]$ & $3416 \mathrm{w}$ & $3271 \mathrm{w}$ & $1672 \mathrm{~s}$ & $1638 \mathrm{w}$ & $1590 \mathrm{~m}$ & $3663-2800 \mathrm{br}$ \\
\hline cis- $\left[\mathrm{PdCl}_{2}(\mathrm{cyt})(\mathrm{gua})\right]$ & $3323 \mathrm{w}$ & $3170 \mathrm{w}$ & $1698 \mathrm{~s}$ & $1638 s$ & $1567 \mathrm{~m}$ & $3618-2587$ br \\
\hline Cytosine & $3372 \mathrm{w}$ & $3166 \mathrm{w}$ & $1668 s$ & $1620 \mathrm{~s}$ & $1534 \mathrm{~m}$ & $3500-2500 \mathrm{br}$ \\
\hline Adenine & $3364 \mathrm{w}$ & $3230 \mathrm{w}$ & - & $1672 \mathrm{~s}$ & $1601 \mathrm{~m}$ & $3394-2500$ br \\
\hline Guanine & $3308 \mathrm{w}$ & $3114 \mathrm{w}$ & $1705 \mathrm{~s}$ & $1631 \mathrm{~s}$ & $1563 \mathrm{~m}$ & $3390-2500 \mathrm{br}$ \\
\hline
\end{tabular}

$v_{\mathrm{as}}$ : antisymmetric stretching, $v_{s}:$ symmetric stretching, $\delta_{s}:$ symmetric bending, s: strong, w: weak, br: broad, and m: medium.

TABLE 2: Far IR/ $\mathrm{cm}^{-1}$ bands for the palladium(II) complexes.

\begin{tabular}{lcc}
\hline Complex & $v_{s}(\mathrm{Pd}-\mathrm{Cl})$ & $v_{s}(\mathrm{Pd}-\mathrm{N})$ \\
\hline cis- $\left[\mathrm{PdCl}_{2}(\right.$ cyt $)($ gua $\left.)\right]$ & $389 \mathrm{w}, 312 \mathrm{w}$ & $282 \mathrm{w}, 238 \mathrm{w}$ \\
cis- $\left[\mathrm{PdCl}_{2}(\right.$ cyt $\left.)(\mathrm{ad})\right]$ & $386 \mathrm{w}, 311 \mathrm{w}$ & $281 \mathrm{w}, 227 \mathrm{w}$ \\
cis- $\left[\mathrm{PdCl}_{2}\right.$ (cyt)(gua) & $364 \mathrm{w}, 339 \mathrm{w}$ & $283 \mathrm{w}, 248 \mathrm{w}$ \\
\hline
\end{tabular}

22.85; Cl, 15.33. UV-Vis $\lambda(\mathrm{nm})(\varepsilon): 290\left(14001 \mathrm{M}^{-1} \mathrm{~cm}^{-1}\right)$, $333\left(3071 \mathrm{M}^{-1} \mathrm{~cm}^{-1}\right), 407\left(784 \mathrm{M}^{-1} \mathrm{~cm}^{-1}\right), 531\left(761 \mathrm{M}^{-1} \mathrm{~cm}^{-1}\right)$. $\Lambda_{m}\left(R^{2}\right): 15.32 \Omega^{-1} \mathrm{~cm}^{-2} \mathrm{~mol}^{-1}(0.925) \cdot \mu_{\mathrm{eff}}=0$.

3.4. IR Spectra. Important vibrational bands were selected by comparing the FTIR spectra of the complexes with those of the respective free nucleobase ligands. The symmetric and antisymmetric $\mathrm{N}-\mathrm{H}$ stretching frequencies of the complexes were observed in the range of $3424-3170 \mathrm{~cm}^{-1}$. These peaks were compared with those of the free ligands which appear between 3372 and $3114 \mathrm{~cm}^{-1}$. The observed shifts can be attributed to hydrogen bonding and other noncovalent interactions in the solid state of these metal complexes $[35,36]$. These observations are supported by the broadening of the spectra observed at $3663-2500 \mathrm{~cm}^{-1}$ [36]. Also observed around $1605-1567 \mathrm{~cm}^{-1}$ are important symmetric $\mathrm{NH}_{2}$ bending vibrations of the ligands which showed slight shifts as compared to those of the free ligands. Furthermore, peaks corresponding to the ring stretching frequencies $v_{s} \mathrm{C}=\mathrm{N}$ between $1620-1567 \mathrm{~cm}^{-1}$ in the free ligands were found to have shifted to $1634-1638 \mathrm{~cm}^{-1}$ in the metal complexes, suggesting the involvement of the ring $\mathrm{C}=\mathrm{N}$ group in coordinating to the metal center $[25,36]$. The farIR region also revealed bands corresponding to $v(\mathrm{Pd}-\mathrm{Cl})$ and $v(\mathrm{Pd}-\mathrm{N})$ vibrations which are absent in the spectra of the free ligands. The FTIR spectra of the complexes are summarized in Tables 1 and 2.

3.5. ${ }^{1} H$-NMR Spectra. A comparison of the ${ }^{1} \mathrm{H}$-NMR spectra of the complexes with those of the free ligands show downfield shifts in the proton signals upon complexation to the palladium(II) ion. As shown in Table 3, the $\mathrm{NH}_{2}$ cytosine protons of cis- $\left[\mathrm{PdCl}_{2}(\mathrm{Gua})(\mathrm{Cyt})\right]$ which are directly adjacent to the coordinating $\mathrm{N} 3$ ring nitrogen show a downfield shift from 7.06 to $7.70 \mathrm{ppm}$ in the complex. Similarly, the $\mathrm{NH}_{2}$ protons of guanine observed in the free ligand at $5.57 \mathrm{ppm}$ was shifted to $5.95 \mathrm{ppm}$ showing that these protons

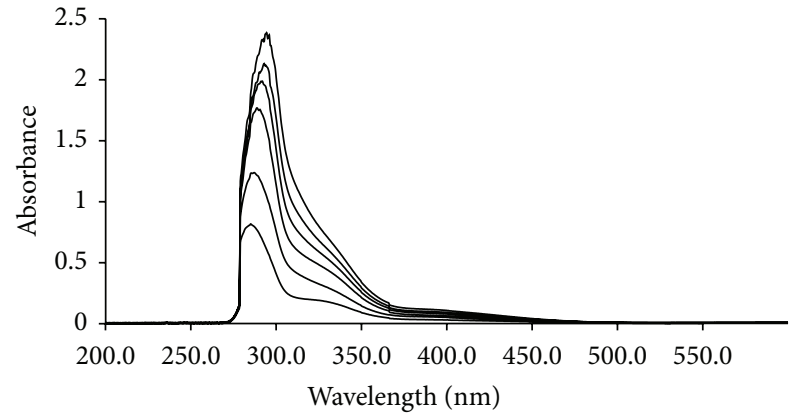

FIgURE 1: Electronic absorption spectra of cis-[PdCl2(Cyt)(Gua)] showing bathochromism with increasing concentration.

experienced strong deshielding effects upon complexation [37]. Similar chemical shifts were observed for the remaining protons as shown in Table 3 . Figure 2 shows the proposed structures of the complexes with labeled atoms.

3.6. Electronic Absorption Spectra, Conductivity, and Magnetic Measurements. The electronic spectra of the complexes were recorded in DMSO $\left(10^{-3} \mathrm{M}\right)$. This was used to study the effect of complexation on the splitting of the d orbitals in the $\mathrm{Pd}(\mathrm{II})$ ion. Significant absorption bands were observed in the region of $280-290,331-333,403-407$, and $531 \mathrm{~nm}$. These transitions may be attributed to intraligand $\pi-\pi^{*}$ as well as the spin allowed LMCT $\mathrm{d}-\mathrm{d}$ transitions of

$$
\begin{gathered}
{ }^{1} \mathrm{~A}_{1 \mathrm{~g}}\left(\mathrm{~d}_{x}{ }^{2}-\mathrm{d}_{y}{ }^{2}\right) \longleftarrow{ }^{1} \mathrm{~A}_{2 \mathrm{~g}}\left(\mathrm{~d}_{x y}\right), \\
{ }^{1} \mathrm{~A}_{1 \mathrm{~g}}\left(\mathrm{~d}_{x}{ }^{2}-\mathrm{d}_{y}{ }^{2}\right) \longleftarrow{ }^{1} \mathrm{E}_{\mathrm{g}}\left(\mathrm{d}_{x z}, \mathrm{~d}_{y z}\right), \\
{ }^{1} \mathrm{~A}_{1 \mathrm{~g}}\left(\mathrm{~d}_{x}{ }^{2}-\mathrm{d}_{y}{ }^{2}\right) \longleftarrow{ }^{1} \mathrm{~B}_{1 \mathrm{~g}}\left(\mathrm{~d}_{z}{ }^{2}\right),
\end{gathered}
$$

respectively [37]. These transitions confirm the square planar $\left(\mathrm{D}_{4 \mathrm{~h}}\right)$ geometry of the $\mathrm{Pd}(\mathrm{II})$ ion [31]. Bathochromism was also observed in the spectra of these complexes with increasing concentration as exemplified in Figure 1. This shift in wavelength can be attributed to strong intermolecular hydrogen bonding, a phenomenon which can be likened to the intercalative mode of bonding involving a strong $\pi-\pi^{*}$ stacking interaction between aromatic chromophores and DNA bases [38-40].

The molar conductivities of the complexes measured in DMSO $\left(10^{-3} \mathrm{M}\right)$ was between 13.58 and $18.48 \Omega^{-1} \mathrm{~cm}^{-2} \mathrm{~mol}^{-1}$ 


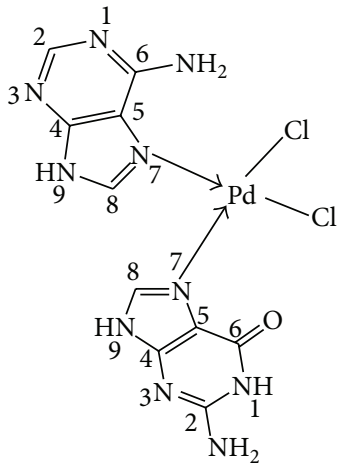

cis- $\left[\mathrm{PdCl}_{2}(\mathrm{Ad})(\mathrm{Gua})\right]$

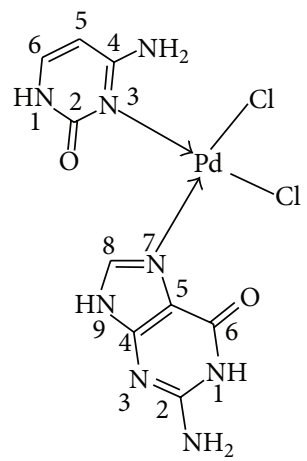

cis- $\left[\mathrm{PdCl}_{2}[(\mathrm{Cyt})(\mathrm{Gua})]\right.$<smiles>NC1=NC=CNN1C(Cl)(Cl)Cl</smiles>

cis- $\left[\mathrm{PdCl}_{2}(\mathrm{Cyt})(\mathrm{Ad})\right]$

FIgURE 2: Proposed structures of the palladium(II) chloride complexes.

TABLE 3: ${ }^{1} \mathrm{H}-\mathrm{NMR}$ data of the complexes and the free nucleobase ligands.

\begin{tabular}{|c|c|}
\hline Complex & $\mathrm{H}-\mathrm{NMR}^{\mathrm{a}}$ \\
\hline cis- $\left[\mathrm{PdCl}_{2}(\right.$ cyt $)($ gua $\left.)\right]$ & $\begin{array}{l}5.56\left(1 \mathrm{H}, \mathrm{s}, \mathrm{H}-5 \text { (cyt)), } 7.40(1 \mathrm{H}, \mathrm{s}, \mathrm{H}-6(\text { cyt })), 7.70\left(\mathrm{~s}, \mathrm{NH}_{2}(\mathrm{cyt})\right), 11.27(1 \mathrm{H}, \mathrm{s}, \mathrm{H}-1(\mathrm{cyt})), 5.95\left(\mathrm{~s}, \mathrm{NH}_{2} \text { (gua)), }\right.\right. \\
8.83(1 \mathrm{H}, \mathrm{s}, \mathrm{H}-8 \text { (gua)), } 9.40(1 \mathrm{H}, \mathrm{s}, \mathrm{H}-9 \text { (gua) }), 12.03(1 \mathrm{H}, \mathrm{s}, \mathrm{H}-1 \text { (gua)). }\end{array}$ \\
\hline cis- $\left[\mathrm{PdCl}_{2}(\mathrm{cyt})(\mathrm{ad})\right]$ & $\begin{array}{l}5.90(1 \mathrm{H}, \mathrm{s}, \mathrm{H}-5(\mathrm{cyt})), 7.71\left(\mathrm{~s}, \mathrm{NH}_{2}(\mathrm{cyt})\right), 8.13(1 \mathrm{H}, \mathrm{s}, \mathrm{H}-6(\mathrm{cyt})), 2.01(1 \mathrm{H}, \mathrm{s}, \mathrm{H}-1(\mathrm{cyt})), 7.70\left(\mathrm{~s}, \mathrm{NH}_{2}(\mathrm{ad})\right) \\
8.38(1 \mathrm{H}, \mathrm{s}, \mathrm{H}-2(\mathrm{ad})), 9.37(1 \mathrm{H}, \mathrm{s}, \mathrm{H}-8(\mathrm{ad})), 12.00(1 \mathrm{H}, \mathrm{s}, \mathrm{H}-9(\mathrm{ad}))\end{array}$ \\
\hline cis- $\left[\mathrm{PdCl}_{2}(\mathrm{ad})(\mathrm{gua})\right]$ & $\begin{array}{l}8.33\left(\mathrm{~s}, \mathrm{NH}_{2}(\mathrm{ad})\right), 8.78(1 \mathrm{H}, \mathrm{s}, \mathrm{H}-8(\mathrm{ad})), 9.20(1 \mathrm{H}, \mathrm{s}, \mathrm{H}-2(\mathrm{ad})), 13.45(1 \mathrm{H}, \mathrm{s}, \mathrm{H}-9(\mathrm{ad})), 6.63\left(\mathrm{~s}, \mathrm{NH}_{2}(\text { gua })\right) \\
8.29(1 \mathrm{H}, \mathrm{s}, \mathrm{H}-8(\text { gua })), 11.17(1 \mathrm{H}, \mathrm{s}, \mathrm{H}-9(\text { gua })), 14.06(1 \mathrm{H}, \mathrm{s}, \mathrm{H}-1 \text { (gua }))\end{array}$ \\
\hline Cytosine & $5.56(1 \mathrm{H}, \mathrm{s}, \mathrm{H}-5), 7.06\left(\mathrm{~s}, \mathrm{NH}_{2}\right), 7.32(1 \mathrm{H}, \mathrm{s}, \mathrm{H}-6), 10.56(1 \mathrm{H}, \mathrm{s}, \mathrm{H}-9)$ \\
\hline Adenine & $7.11\left(\mathrm{~s}, \mathrm{NH}_{2}\right), 8.10(2 \mathrm{H}, \mathrm{s}, \mathrm{H}-2$ and $\mathrm{H}-8), 12.86(1 \mathrm{H}, \mathrm{s}, \mathrm{H}-9)$ \\
\hline Guanine & $5.57\left(\mathrm{~s}, \mathrm{NH}_{2}\right), 7.08(1 \mathrm{H}, \mathrm{s}, \mathrm{H}-8), 10.55(1 \mathrm{H}, \mathrm{s}, \mathrm{H}-9)$ \\
\hline
\end{tabular}

${ }^{\mathrm{a}} 25^{\circ} \mathrm{C}$ in DMSO-d 6 $\delta[\mathrm{ppm}]$.

indicating the nonelectrolyte nature of these complexes [4143]. The effective magnetic moment measurement at room temperature confirmed their diamagnetic characters of these complexes thus square-planar geometry.

Based on the above discussion of results and the analytical data obtained from the metal and chloride content analyses we suggest that the structural formulae of the complexes are as given in Figure 2.

3.7. In Vitro Cytotoxicity. The growth inhibition effect of the complexes as well as the free ligands was measured on two leukemia cell lines (human promyelocytic leukemia (HL60) and human histiocytic leukemia (U937)) with curcumin as a positive control. The results as expressed by $\mathrm{IC}_{50}$ values $(\mu \mathrm{M})$ are presented in Table 4 . Of the three nucleobase ligands, guanine was the only cytotoxin on HL60 within the working concentration of $0-200 \mu \mathrm{M}$. It reported an $\mathrm{IC}_{50}$ value of $71.38 \pm 9.01 \mu \mathrm{M}$. Guanine was also cytotoxic against U937, recording a value of $53.53 \pm 8.55 \mu \mathrm{M}$.

All the three mixed ligand complexes were significantly cytotoxic with the exception of cis- $\left[\mathrm{PdCl}_{2}(\mathrm{Cyt})(\mathrm{Ad})\right]$ which did not show any activity on HL60 within the working concentration. From Table 4, cis- $\left[\mathrm{PdCl}_{2}(\mathrm{Ad})(\mathrm{Gua})\right]$ was the most cytotoxic against both cell lines with $\mathrm{IC}_{50}$ values of $11.45 \pm 2.91$ and $8.31 \pm 1.44 \mu \mathrm{M}$ on the respective cell lines. It was more cytotoxic than the positive control (curcumin)
TABLE 4: $\mathrm{IC}_{50}$ values of the complexes tested on the respective cell lines.

\begin{tabular}{lcc}
\hline \multirow{2}{*}{ Complex } & \multicolumn{2}{c}{ Cell line } \\
& HL60 & U937 \\
\hline cis-[PdCl $(\mathrm{Cyt})(\mathrm{Gua})]$ & $132.01 \pm 3.44$ & $17.63 \pm 1.25$ \\
cis-[PdCl$(\mathrm{Cyt})(\mathrm{Ad})]$ & $>200$ & $34.56 \pm 2.02$ \\
cis-[PdCl $(\mathrm{Ad})(\mathrm{Gua})]$ & $11.45 \pm 2.91$ & $8.31 \pm 1.44$ \\
Adenine & $>200$ & $>100$ \\
Cytosine & $>200$ & $44.95 \pm 7.11$ \\
Guanine & $71.38 \pm 9.01$ & $53.53 \pm 8.55$ \\
Curcumin & $5.40 \pm 2.55$ & $8.63 \pm 1.94$ \\
\hline
\end{tabular}

on U937 cell line. The high activity of cis- $\left[\mathrm{PdCl}_{2}(\mathrm{Ad})(\mathrm{Gua})\right]$ could be attributed to the bulkiness of the nucleobase ligands which has the tendency to significantly reduce the rate of deactivation by sulphur-containing molecules within the cell $[44,45]$.

3.8. Antioxidant Activity. Various researchers have used scavenging effect of a chemical on DPPH radical as a quick and reliable parameter to measure the in vitro antioxidant activity $[12,13,46]$. This assay is based on the measurement of the decrease in molar absorptivity of DPPH at $517 \mathrm{~nm}$ after reaction with the test compound. 


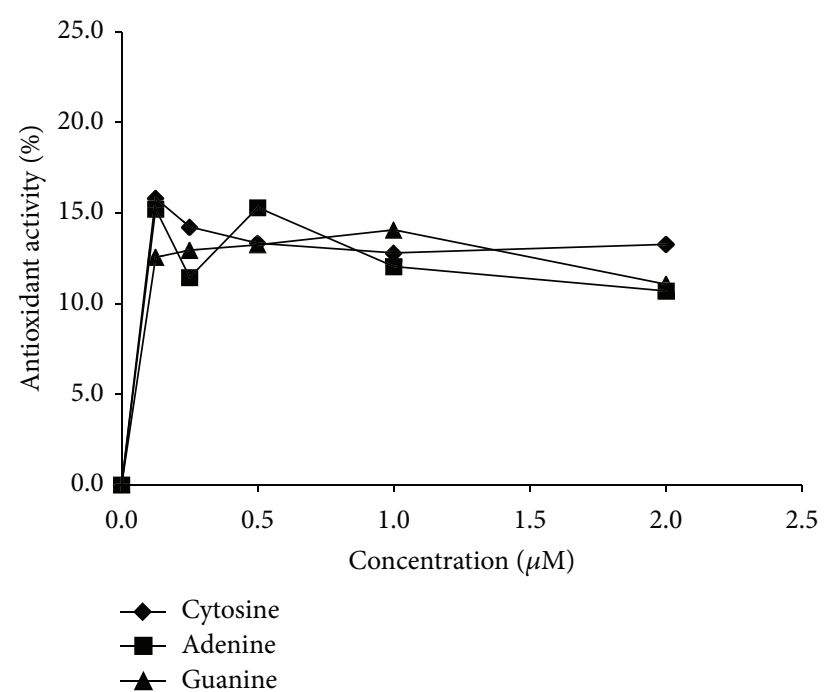

Figure 3: Percent antioxidant activity of the free ligands.

From Figure 3, the antioxidant activity of the free ligands was found to be between 10 and $15 \%$ but, upon complexation, it increased significantly (Figure 4). The increased antioxidant activity of these complexes can be attributed to the downfield shift of the ${ }^{1} \mathrm{H}-\mathrm{NMR}$ signals (Table 3 ). As reported $[12,13]$, this phenomenon is as a result of the electron withdrawing effect of the $\mathrm{Pd}(\mathrm{II})$ ion which facilitates the release of hydrogen to reduce the $\mathrm{DPPH}$ radical. These proton shifts were very profound in cis- $\left[\mathrm{PdCl}_{2}(\mathrm{Ad})(\mathrm{Gua})\right]$ with the $\mathrm{H}-1$ proton of guanine absorbing at a chemical shift of $14.06 \mathrm{ppm}$. This could contribute to the higher activity of cis$\left[\mathrm{PdCl}_{2}(\mathrm{Ad})(\mathrm{Gua})\right]$ with an $\mathrm{EC}_{50}$ (concentration of complexes needed to scavenge $50 \%$ of the initial DPPH concentration) value of $1.00 \mathrm{mM}$.

\section{Conclusion}

In this study, we reported the synthesis and spectroscopic characterization of mixed ligand $\mathrm{Pd}$ (II) chloride complexes bearing the nucleobases cytosine, adenine, and guanine. A four-coordinated square-planar geometry was proposed for these complexes based on spectroscopic and magnetic measurements. The ligands and the metal complexes were tested for their antioxidant and in vitro cytotoxic activities. All the complexes were significantly cytotoxic with cis$\left[\mathrm{PdCl}_{2}(\mathrm{Ad})(\mathrm{Gua})\right]$ showing higher activity than the positive control (curcumin) on U937 cell line. All the complexes also show significant free radical scavenging ability when tested against DPPH.

\section{Conflict of Interests}

The authors declare that there is no conflict of interests regarding the publication of this paper.

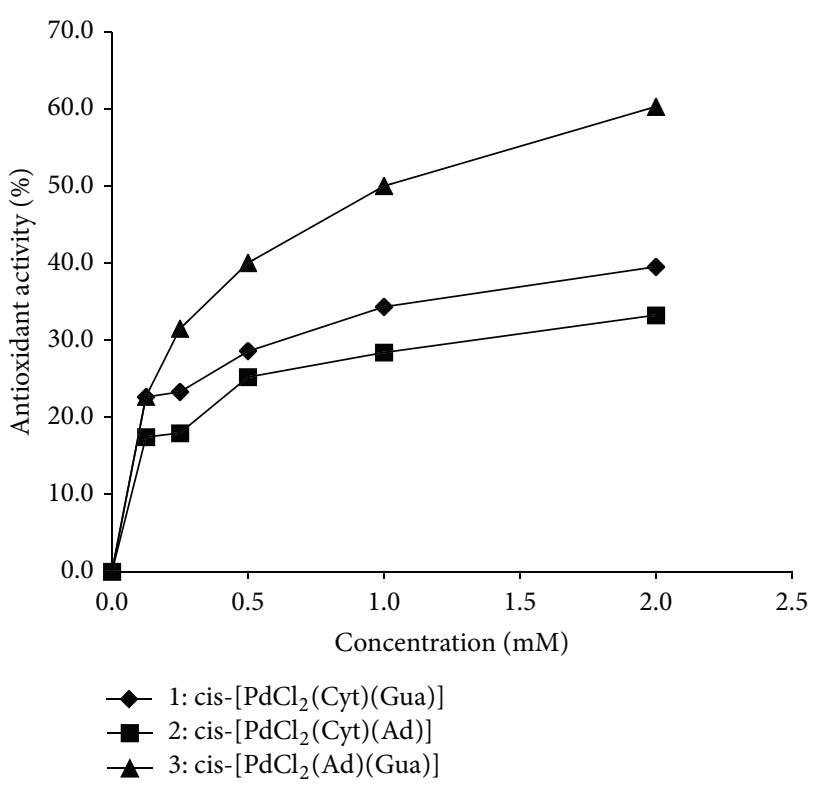

FIgURE 4: Percent antioxidant activity of the mixed ligand complexes.

\section{Acknowledgments}

The authors wish to thank the Government of Ghana for financial support, the Chemistry Department of the University of Johannesburg, South Africa, for ${ }^{1} \mathrm{H}-\mathrm{NMR}$ determination. They also appreciate the technical support of staff of the Chemistry Department, University of Cape Coast, Ghana, as well as the Clinical Pathology Department of the Noguchi Memorial Institute for Medical Research, University of Ghana, where antioxidant and in vitro cytotoxicity tests were carried out.

\section{References}

[1] B. T. Khan, S. V. Kumari, and G. N. Goud, "Mixed ligand complexes of platinum (II) with $\alpha$-amino acids and purines and pyrimidines," Journal of Coordination Chemistry, vol. 12, no. 1, pp. 19-25, 1982.

[2] W. Brüning, E. Freisinger, M. Sabat, R. K. O. Sigél, and B. Lippert, "N1 and N3 linkage Isomers of neutral and protonated cytosine with trans $\left[\left(\mathrm{CH}_{3} \mathrm{NH}_{2}\right)_{2} \mathrm{Pt}(\mathrm{II})\right]$," Chemistry, vol. 8, no. 20, pp. 4681-4692, 2002.

[3] R. Kobetić, D. Gembarovski, A. Višnjevac, B. Žinić, and V. Gabelica-Marković, "ESI-MS studies of palladium (II) complexes with 1-( $\rho$-toluenesulfonyl) cytosine/cytosinato ligands," Journal of Mass Spectrometry, vol. 45, no. 1, pp. 51-64, 2010.

[4] E. G. Bardají, E. Freisinger, B. Costisella et al., "Mixed-metal (platinum, palladium), mixed-pyrimidine (uracil, cytosine) self-assembling metallacalix[n]arenes: dynamic combinatorial chemistry with nucleobases and metal species," Chemistry, vol. 13, no. 21, pp. 6019-6039, 2007.

[5] D. Holthenrich, E. Zangrando, E. Chiarparin, B. Lippert, and L. Randaccio, "Cytosine nucleobase as a tridentate ligand: metal binding to $\mathrm{N} 3, \mathrm{~N} 4$ and $\mathrm{O} 2$ in the trinuclear complex 
cis- $\left[\mathrm{Pt}\left(\mathrm{NH}_{3}\right)_{2}(\mathrm{mcyt})_{2} \mathrm{Pd}(\mathrm{en})_{2}\right]-\left[\mathrm{NO}_{3}\right]_{4} \cdot \mathrm{H}_{2} \mathrm{O}$ (mcyt = 1-methylcytosinate, en = ethane-1,2-diamine)," Journal of the Chemical Society, Dalton Transactions, no. 22, pp. 4407-4410, 1997.

[6] C. Navarro-Ranninger, E. I. Montero, I. López-Solera, J. R. Masaguer, and B. Lippert, "A cyclometallated Pd(II) complex containing a cytosine model nucleobase," Journal of Organometallic Chemistry, vol. 558, no. 1-2, pp. 103-110, 1998.

[7] A. S. Abu-Surrah, K. A. Abu Safieh, I. M. Ahmad et al., "New palladium(II) complexes bearing pyrazole-based Schiff base ligands: synthesis, characterization and cytotoxicity," European Journal of Medicinal Chemistry, vol. 45, no. 2, pp. 471-475, 2010.

[8] A. Pañella, J. Pons, J. García-Antón, X. Solans, M. Font-Bardia, and J. Ros, "Synthesis of new palladium(II) complexes containing hemilabile N(alkylamino)pyrazole ligands: spectroscopic analysis and crystal structure of $\mathrm{PdCl}(\mathrm{ddae}) \mathrm{Cl} \cdot \mathrm{H}_{2} \mathrm{O}$ ddae $=\mathrm{Bis}[2-$ (3,5-dimethyl-1-pyrazolyl)ethyl] ethylamine," European Journal of Inorganic Chemistry, no. 8, pp. 1678-1685, 2006.

[9] S. Pérez-Yáňez, O. Castillo, J. Capeda, J. P. Garcia-Teran, A. Luque, and P. Roman, "Supramolecular architectures of metaloxalato complexes containing purine nucleobases," Inorganica Chimica Acta, 2010.

[10] G. Cervantes, J. J. Fiol, A. Terrón et al., "Synthesis and characterization of nickel(II) complexes of purine and pyrimidine bases. Crystal and molecular structure of trans-bis(cytosine$\mathrm{O}^{2}$ )bis(ethylenediamine)nickel(II) bis(tetraphenylborate). An unusual metal binding mode of cytosine," Inorganic Chemistry, vol. 29, no. 26, pp. 5168-5173, 1990.

[11] X. Zhong, W. Slough, R. Pandey, and C. Friedrich, "Interaction of nucleobases with silicon nanowires: a first principle study," Chemical Physics Letters, vol. 553, pp. 55-58, 2012.

[12] A. A. Al-Amiery, A. A. H. Kadhum, and A. B. Mohammed, "Antifungal and antioxidant activities of pyrolidone thiosemicarbazone complexes," Bioinorganic Chemistry and Applications, vol. 2012, Article ID 795812, 6 pages, 2012.

[13] A. Choudhary, R. Sharma, M. Nagar, M. Mohsin, and H. S. Meena, "Synthesis, characterization and antioxidant activity of some transition metal complexes with terpenoid derivatives," Journal of the Chilean Chemical Society, vol. 56, no. 4, pp. 911917, 2011.

[14] A. S. Mildvan and M. Cohn, "Kinetic and magnetic resonance studies of the pyruvate kinase reaction. II. Complexes of enzyme, metal, and substrates," Journal of Biological Chemistry, vol. 241, no. 5, pp. 1178-1193, 1966.

[15] G. M. R. Tombo and D. Bellus, "Chiralität und pflanzenschutz," Angewandte Chemie, vol. 103, no. 10, pp. 1219-1241, 1991.

[16] A. A. El-Sherif, M. R. Shehata, M. M. Shoukry, and M. H. Barakat, "Thermodynamic investigation and mixed-ligand complex formation of 1,4-bis-(3-aminopropyl)-piperazine and biorelevant ligands," Bioinorganic Chemistry and Applications, vol. 2012, Article ID 984291, 10 pages, 2012.

[17] A. M. Ryzhakov, M. S. Gruzdev, D. F. Pyreu, E. V. Kozlovskii, and R. S. Kumeev, "Thermodynamics of mixed-ligand complexation of mercury(II) ethylenediaminetetraacetate with histidine and lysine in aqueous solution," Russian Journal of Coordination Chemistry, vol. 36, no. 8, pp. 565-571, 2010.

[18] R. Ahuja and K. Dwivedi, “Thermodynamic equilibrium constants of mixed-ligand complexes of $\mathrm{Cu}$ (II) with ethyleneglycolbis(2-aminoethylether)- $\mathrm{N}, \mathrm{N}, \mathrm{N}^{\prime}, \mathrm{N}^{\prime}$ tetraacetic acid as primary and alanine and phenylalanine as secondary ligands," Asian Journal of Chemistry, vol. 5, no. 1, pp. 54-59, 1993.
[19] D. B. Berezin, O. V. Shukhto, and P. A. Shatunov, "Effect of ligand nonplanarity and solvent nature on the kinetic stability of zinc porphyrin complexes," Russian Journal of General Chemistry, vol. 78, no. 5, pp. 997-1004, 2008.

[20] G. Rajendran and C. R. K. Kumari, "Kinetic and antimicrobial studies on some novel mixed ligand complexes of thorium(IV) and dioxouranium(VI) ions," Asian Journal of Chemistry, vol. 16, no. 2, pp. 643-648, 2004.

[21] J. Nemes, I. Tóth, and L. Zékány, "Formation kinetics of an aluminium(III)-ethylenedinitrilotetraacetate-fluoride mixed ligand complex," Journal of the Chemical Society, Dalton Transactions, no. 16, pp. 2707-2713, 1998.

[22] K. Rai and F. Khan, "A study of stability constants of [ZnL-aminoacidate-vitamin-PP] systems," American Journal of Chemistry, vol. 2, no. 6, pp. 299-305, 2012.

[23] J. Reedijk, "Metal-ligand exchange kinetics in platinum and ruthenium complexes: significance for effectiveness as anticancer drugs," Platinum Metals Review, vol. 52, no. 1, pp. 2-11, 2008.

[24] Y. Zhang, X. Wang, W. Fang et al., "Synthesis and in vitro antitumor activity of two mixed-ligand oxovanadium(IV) complexes of schiff base and phenanthroline," Bioinorganic Chemistry and Applications, vol. 2013, Article ID 437134, 14 pages, 2013.

[25] Y. Prashanthi, K. Kiranmai, Ira, K. Sathish Kumar, V. K. Chityala, and Shivaraj, "Spectroscopic characterization and biological activity of mixed-ligand complexes of $\mathrm{Ni}$ (II) with 1,10-phenanthroline and heterocyclic schiff bases," Bioinorganic Chemistry and Applications, vol. 2012, Article ID 948534, 8 pages, 2012.

[26] H. Khan, A. Badshah, M. Said et al., "Anticancer metallopharmaceutical agents based on mixed-ligand palladium(II) complexes with dithiocarbamates and tertiary organophosphine ligands," Applied Organometallic Chemistry, vol. 27, no. 7, pp. 387-395, 2013.

[27] G. D. Geromichalos, G. A. Katsoulos, D. T. Trafalis, C. C. Hadjikostas, and A. Papageorgiou, "Synergistic interaction between a novel mixed ligand copper(II) chelate complex and a panel of anticancer agents in T47D human breast cancer cells in vitro," Journal of B.U.ON, vol. 10, no. 2, pp. 235-240, 2005.

[28] M. Paula, M. Marques, R. Valero, S. F. Parker, J. Tomkinson, and L. A. E. Batista de Carvalho, "Polymorphism in cisplatin anticancer drug," The Journal of Physical Chemistry B, vol. 117, no. 21, pp. 6421-6429, 2013.

[29] K. Pi-Chang and F. D. Rochon, "Palladium compounds of pyrimidine and pyridine derivatives-proposed structure assignment changes," Canadian Journal of Chemistry, vol. 59, no. 23, pp. 3293-3296, 1981.

[30] A. M. A. Khader and K. S. Prasad, "Extractive spectrophotometry of palladium(II) with 3,4,5-trimethoxybenzaldehyde thiosemicarbazone," Turkish Journal of Chemistry, vol. 20, no. 3, pp. 222-227, 1996.

[31] G. L. Meissler and D. A. Tarr, Inorganic Chemistry, Pearson Education Inc, Upper Saddle River, NJ, USA, 3rd edition, 2004.

[32] D. P. Shoemaker, C. W. Garland, J. I. Steinfeld, and J. W. Nibler, Experiments in Physical Chemistry, McGraw-Hill, New York, NY, USA, 4th edition, 1981.

[33] W. Gao, S. Bussom, S. P. Grill et al., "Structure-activity studies of phenanthroindolizidine alkaloids as potential antitumor agents," Bioorganic and Medicinal Chemistry Letters, vol. 17, no. 15, pp. 4338-4342, 2007.

[34] M. S. Blois, "Antioxidant determinations by the use of a stable free radical," Nature, vol. 181, no. 4617, pp. 1199-1200, 1958. 
[35] A. I. Matesanz, J. M. Pérez, P. Navarro, J. M. Moreno, E. Colacio, and P. Souza, "Synthesis and characterization of novel palladium(II) complexes of bis(thiosemicarbazone). Structure, cytotoxic activity and DNA binding of Pd(II)-benzyl bis(thiosemicarbazonate)," Journal of Inorganic Biochemistry, vol. 76, no. 1, pp. 29-37, 1999.

[36] P. A. Ajibade and O. G. Idemudia, "Synthesis, characterization and antibacterial studies of Pd(II) and Pt(II) complexes of some diaminopyrimidine derivatives," Bioinorganic Chemistry and Applications, vol. 2013, Article ID 549549, 8 pages, 2013.

[37] E. Szlyk, A. Grodzicki, L. Pazderski et al., "Palladium(II) chloride complexes with 1, 2, 4-triazolo[1,5-a]-pyrimidines: $\mathrm{x}$-ray, ${ }^{15} \mathrm{~N}-{ }^{1} \mathrm{H}$ NMR and ${ }^{15} \mathrm{~N}$ CP MAS studies," Journal of the Chemical Society, Dalton Transactions, no. 6, pp. 867-872, 2000.

[38] J. Liu, T. Zhang, T. Lu et al., "DNA-binding and cleavage studies of macrocyclic copper(II) complexes," Journal of Inorganic Biochemistry, vol. 91, no. 1, pp. 269-276, 2002.

[39] H. Wu, F. Kou, F. Jai, B. Liu, J. Yuan, and Y. Bai, "Synthesis and Characterization of the ligand based on benzimidazole and its copper complex: DNA-binding and antioxidant activity," Bioinorganic Chemistry and Applications, vol. 2011, Article ID 105431, 11 pages, 2011.

[40] G. Aragay, J. Pons, J. García-Antón et al., "Synthesis and Characterization of New Palladium(II) Complexes Containing N-Alkylamino-3,5-diphenylpyrazole Ligands. Crystal Structure of $[\mathrm{PdCl}(\mathrm{L} 2)](\mathrm{BF} 4) \quad \mathrm{L} 2=$ bis[2-(3,5-diphenyl-1pyrazolyl)ethylamine," Australian Journal of Chemistry, vol. 62, no. 5, pp. 475-482, 2009.

[41] W. J. Geary, "The use of conductivity measurements in organic solvents for the characterisation of coordination compounds," Coordination Chemistry Reviews, vol. 7, no. 1, pp. 81-122, 1971.

[42] Ü. Ö. Özmen and G. Olgun, "Synthesis, characterization and antibacterial activity of new sulfonyl hydrazone derivatives and their nickel(II) complexes," Spectrochimica Acta A, vol. 70, no. 3, pp. 641-645, 2008.

[43] C. M. Sharaby, "Synthesis, spectroscopic, thermal and antimicrobial studies of some novel metal complexes of Schiff base derived from [N1-(4-methoxy-1,2,5-thiadiazol3-yl)sulfanilamide] and 2-thiophene carboxaldehyde," Spectrochimica Acta A, vol. 66, no. 4-5, pp. 1271-1278, 2007.

[44] K. A. Gelmon, D. Stewart, K. N. Chi et al., "A phase I study of AMD473 and docetaxel given once every 3 weeks in patients with advanced refractory cancer: a National Cancer Institute of Canada-Clinical Trials Group trial, IND 131," Annals of Oncology, vol. 15, no. 7, pp. 1115-1122, 2004.

[45] L. Kelland, "Broadening the clinical use of platinum drug-based chemotherapy with new analogues: satraplatin and picoplatin," Expert Opinion on Investigational Drugs, vol. 16, no. 7, pp. 10091021, 2007.

[46] A. A. H. Kadhum, A. B. Mohamad, A. A. Al-Amiery, and M. S. Takriff, "Antimicrobial and antioxidant activities of new metal complexes derived from 3-aminocoumarin," Molecules, vol. 16, no. 8, pp. 6969-6984, 2011. 

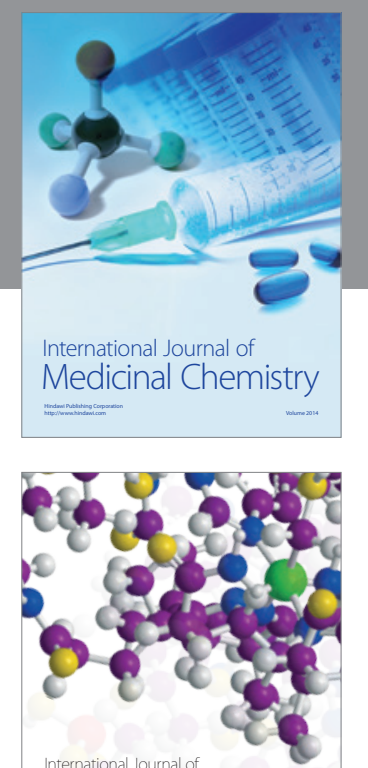

\section{Carbohydrate} Chemistry

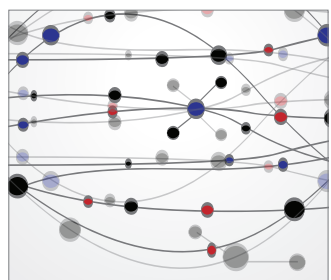

The Scientific World Journal
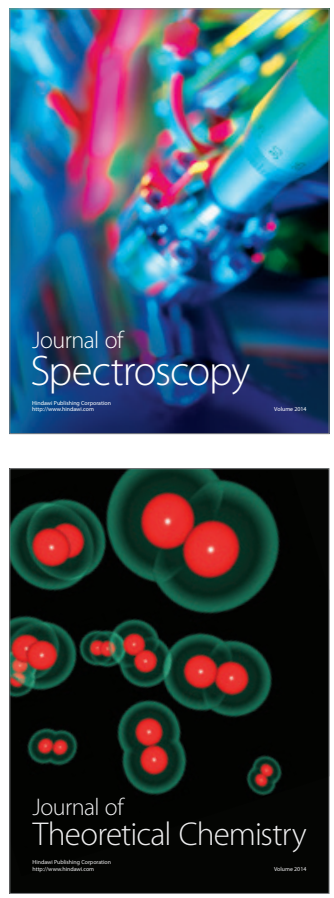
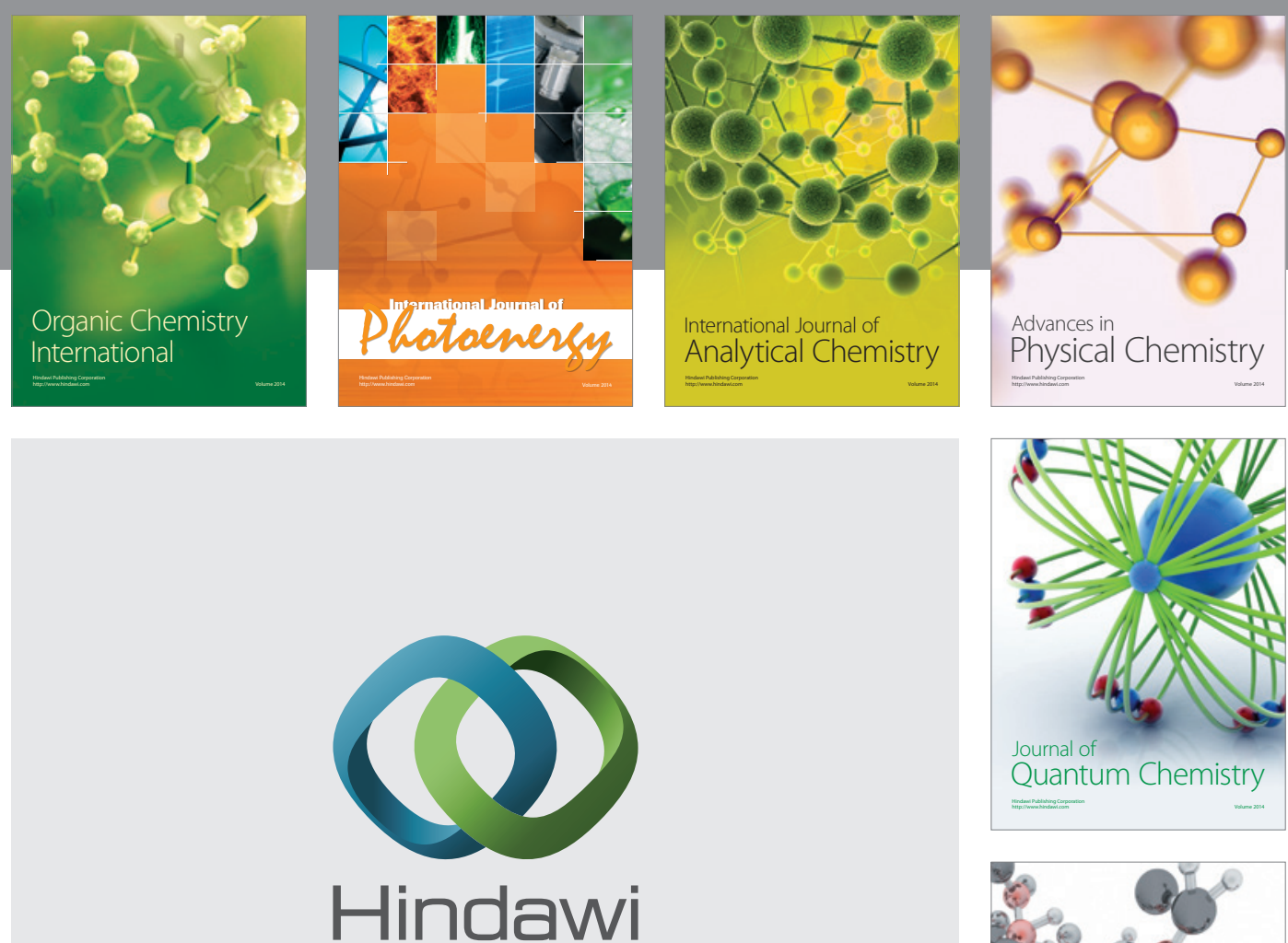

Submit your manuscripts at

http://www.hindawi.com

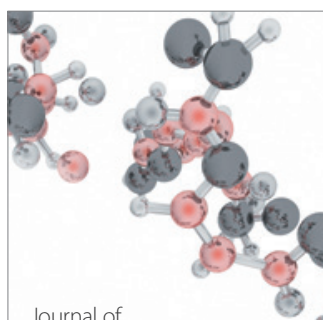

Analytical Methods

in Chemistry

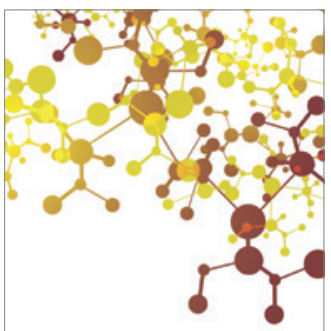

Journal of

Applied Chemistry

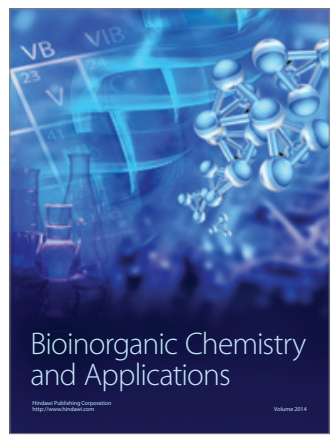

Inorganic Chemistry
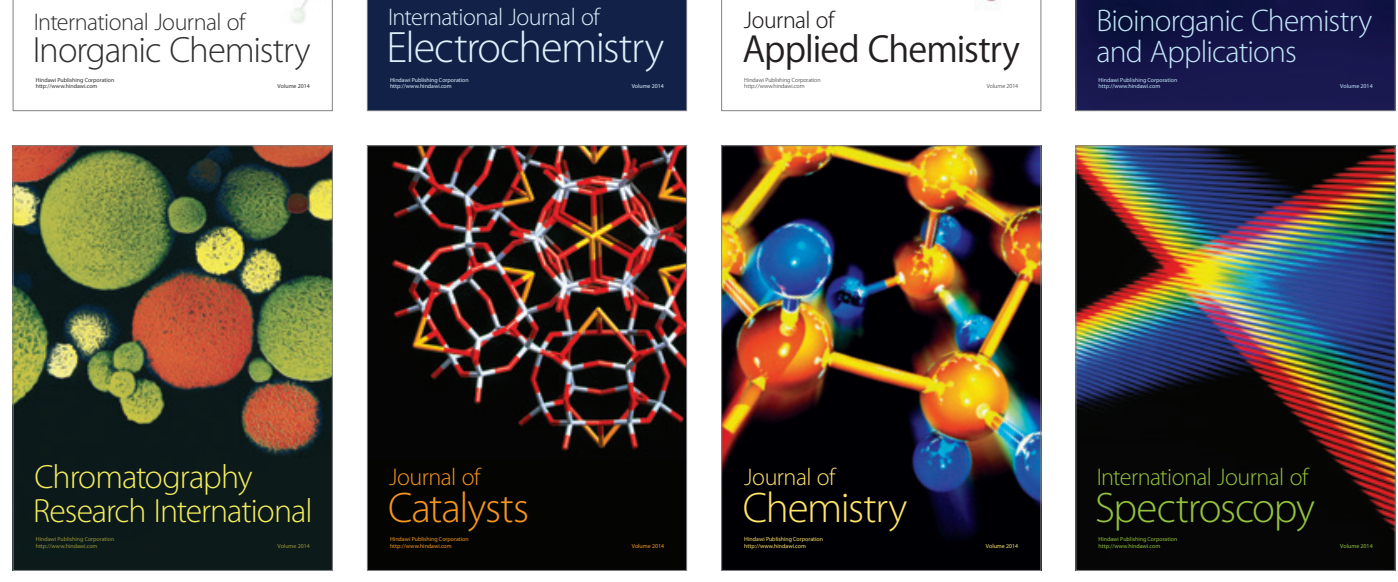